\title{
COMPARISON OF OPTIMUM CONDITIONS WHEN EXTRACTING PHAS FROM DIFFERENT WASTE SLUDGE SOURCES
}

\author{
Meng-Shan LU ${ }^{1}$, Long-Li LAI ${ }^{2}$, Yung-Pin TSAI ${ }^{*}$ \\ ${ }^{1}$ Department of Civil Engineering, National Chi Nan University, Puli, Nantou 545, Taiwan, ROC \\ 2 Department of Applied Chemistry, National Chi Nan University, Puli, Nantou 545, Taiwan, ROC
}

Received 05 March 2017; accepted 27 November 2017

\begin{abstract}
Biological wastewater treatment plants produce great amounts of sludge daily. It is a very big loading (cost) for treating the waste sludge. Polyhydroxyalkanoates are a family of polyhydroxyesters. The technologies of extracting PHAs from wasted sewage sludges of municipal wastewater, fermentation industry and husbandry were developed in the study. In the $\mathrm{NaOCl} / \mathrm{SDS}$ extraction technology, the concentration of $\mathrm{NaOCl}$ and liquid-solid ratio are two essential factors directly influencing extraction efficiency. The experimental results verified under the optimal conditions for extracting PHAs, the content of recovered PHAs was $44.2 \pm 0.89 \mathrm{mgPHA} / \mathrm{gVSS}$ and the purity of recovered PHAs was $>99.5 \mathrm{wt} \%$ for the waste sludge from municipal wastewater treatment plants. For fermentation industry sludge, under the adequate extraction conditions for PHAs recovery, the content and purity of recovered PHAs were $18.8 \pm 0.66 \mathrm{mgPHA} / \mathrm{gVSS}$ and $50.6 \pm 6.83 \mathrm{wt} \%$, respectively. For husbandry sludge, the content and purity of recovered PHAs were $33.7 \pm 0.16 \mathrm{mgPHA} / \mathrm{gVSS}$ and $76.7 \pm 5.2 \mathrm{wt} \%$, respectively.
\end{abstract}

Keywords: biodegradable plastic, biopolymers, polyhydroxyalkanoates (PHAs), waste sludge.

\section{Introduction}

Petroleum-based plastic products have already caused considerable waste disposal problems, and replacing conventional plastics with biodegradable plastics is imperative for reducing environment hazards. Polyhydroxyalkanoates (PHAs) are a source for producing biodegradable plastics (Doi, Abe 1990). Over 250 different bacteria, including gram-negative and gram-positive species, have been reported to accumulate in PHAs (Ojumu et al. 2004). PHAs accumulate in cytoplasmic granules that typically have a diameter from 0.2 to $0.5 \mu \mathrm{m}$. The molecular weight of the polymers are in the range from $2 \times 10^{5}$ to $3 \times 10^{6}$ daltons (Urtuvia et al. 2014). PHAs exhibit the properties of biodegradation and biocompatibility (Chen 2003).

The PHA extraction technology involves two issues: (1) The rationality of the method that mainly involves extraction rate, purity, structural changes in PHAs during extraction, process, feasibility of transferring from the laboratory to industry, operation convenience, complexity of processing and degree of environmental pollution, etc. (2) The economy of the extraction process, which mainly involves material costs, energy consumption, facility investment, etc. As PHAs exist in the cells as particles, isolation and extraction are relatively difficult. Therefore, reducing costs is significantly more important for extraction of PHAs. Currently, the most widely used PHA extraction techniques include organic solvent method (Ramsay et al. 1994; Rai et al. 2011; Martino et al. 2014), NaClO digestion (Heinrich et al. 2013; Martino et al. 2014), $\mathrm{NaClO}-\mathrm{CHCl}_{3}$ two-phase extraction (García et al. 2013; López-Abelairas et al. 2015), enzyme digestion, and surfactant- $\mathrm{NaClO}$ method (Madkour et al. 2013; Jiang et al. 2014). However, different bacteria have various cell wall structures and factors of PHA synthesis, and the corresponding extraction methods for PHAs are different. To address the problem of water pollution, the number of wastewater treatment plants has increased rapidly. During the wastewater treatment process, a considerable amount of waste sludge is produced annually. The processing cost for waste sludge exceeds half the total cost of wastewater treatment, resulting in no suitable places being available for waste sludge disposal and presenting wastewater treatment plants with considerable problems. Effective management of solid waste has become environmentally and economically mandatory due to the increase of environmental problems (Ghinea, Gavrilescu 2016). Therefore, a

${ }^{*}$ Corresponding author. E-mail: $y$ ptsai@ncnu.edu.tw 
new technology, which has been patented in the United States and Taiwan, was developed to extract PHAs from waste sludge for producing biodegradable plastics, which can reduce the cost of processing waste sludge and reduce the production costs of biodegradable plastics, thereby accelerating the promotion and application of such plastics.

\section{Materials and methods}

\subsection{Waste sludge sources}

The PHA extraction experiments were performed on the waste sludge from three sources. Table 1 shows the three waste sludge sources, as well as the water quality of the corresponding wastewater treatment plants. Table 2 shows the initial PHA content of the sludge sources.

\subsection{Waste sludge pre-processing step}

To destroy the cell bodies in the sludge for PHA extraction, the waste sludge was centrifuged at $3000 \mathrm{rpm}$ for $20 \mathrm{~min}$, and the supernatant liquor was discarded; subsequently, the step (heating + ultrasound grinding method) indicated in Patent NO. US 8,641,908 B2 was performed for pre-processing the sludge.

\subsection{Sludge extraction method}

After the waste sludge was pre-processed, sodium hypochlorite/sodium dodecyl sulfate $(\mathrm{NaOCl} / \mathrm{SDS})$ was utilized to extract PHAs from the waste sludge using the following steps (Figure 1).

\subsection{Analytical methods}

We referred to Satoh et al. (1996) to analyze the PHA content; gas chromatography-mass spectrometry (GC-MS; GC17A/MS-QP5050A; Shimadzu, Japan) was employed,

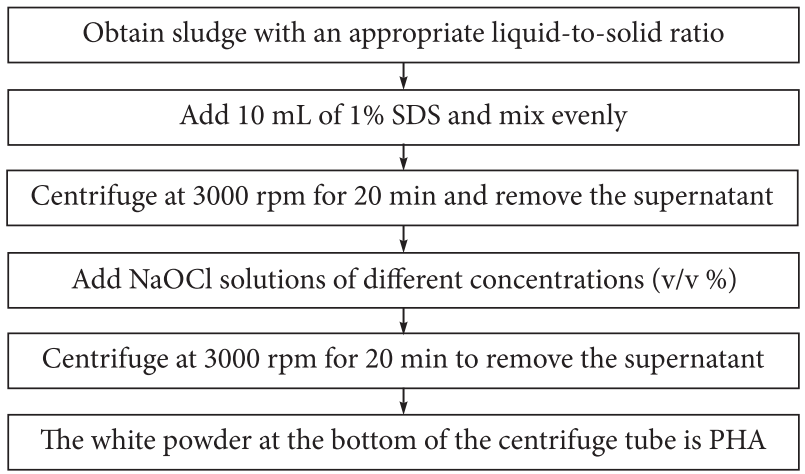

Figure 1. Sludge extraction method

and a BP1 capillary column (SGE Analytical Science, Australia; $25 \mathrm{~m} \times 220 \mathrm{~mm} \times 0.25 \mathrm{~mm}$ ) was used. The temperatures of the detector and injector were $230^{\circ} \mathrm{C}$ and $220^{\circ} \mathrm{C}$, respectively. The initial temperature for the column was set at $70{ }^{\circ} \mathrm{C}$ for $2 \mathrm{~min}$; subsequently, the temperature was increased to $270{ }^{\circ} \mathrm{C}$ at $8{ }^{\circ} \mathrm{C} / \mathrm{min}$, and was maintained for $3 \mathrm{~min}$. The carrier gas of the mass spectrometry was helium with a flow rate of $2 \mathrm{~mL} / \mathrm{min}$. The injection volume of the GC column was $2 \mu \mathrm{L}$, as controlled by an automatic sampler (AOC-20i, Shimadzu) with a split ratio of 1:20. The obtained peak was compared to the standard value in the mass spectrometry database of the National Institute of Standards and Technology (NIST) to acquire the species information and concentration of the sample.

\subsection{PHA purity and content calculation}

The VSS was volatile suspended solids. The PHA content was the sum of polyhydroxybutyrate (PHB) and polyhydroxyvalerate (PHV) contents, and the PHA purity was equal to the ratio of the extracted PHA powder mass (mgPHA/gVSS) to PHA content (mgPHA/gVSS).

Table 1. Water quality of the wastewater treatment plants corresponding to the different waste sludge sources

\begin{tabular}{|c|c|c|c|c|c|c|c|c|c|c|}
\hline \multirow[b]{2}{*}{ Parameters } & \multicolumn{3}{|c|}{ Influent } & \multicolumn{3}{|c|}{ Effluent } & \multicolumn{3}{|c|}{ Removal efficiency } & \multirow[b]{2}{*}{ MLSS (mg/L) } \\
\hline & $\begin{array}{c}\mathrm{COD} \\
(\mathrm{mg} / \mathrm{L})\end{array}$ & $\begin{array}{c}\text { BOD } \\
(\mathrm{mg} / \mathrm{L})\end{array}$ & $\begin{array}{c}\mathrm{SS} \\
(\mathrm{mg} / \mathrm{L})\end{array}$ & $\begin{array}{c}\text { COD } \\
(\mathrm{mg} / \mathrm{L})\end{array}$ & $\begin{array}{c}\text { BOD } \\
(\mathrm{mg} / \mathrm{L})\end{array}$ & $\begin{array}{c}\mathrm{SS} \\
(\mathrm{mg} / \mathrm{L})\end{array}$ & $\begin{array}{c}\text { COD } \\
(\%)\end{array}$ & $\begin{array}{c}\text { BOD } \\
(\%)\end{array}$ & $\begin{array}{l}\text { SS } \\
(\%)\end{array}$ & \\
\hline $\begin{array}{l}\text { Municipal } \\
\text { Wastewater }\end{array}$ & 161 & 100 & 42.0 & 8.07 & 4.84 & 3.18 & $95 \%$ & $95 \%$ & $92 \%$ & $1,800 \sim 2,000$ \\
\hline $\begin{array}{l}\text { Husbandry Industry } \\
\text { Wastewater }\end{array}$ & 5,000 & - & 2,900 & 250 & - & 52.0 & $95 \%$ & - & $98 \%$ & 2,000 \\
\hline $\begin{array}{l}\text { Fermentation } \\
\text { Industry Wastewater }\end{array}$ & 1,800 & - & 200 & 100 & - & 30.0 & $94 \%$ & - & $85 \%$ & 2,000 \\
\hline
\end{tabular}

Table 2. Initial PHA content of the sludge sources

\begin{tabular}{|l|c|c|c|c|}
\hline \multicolumn{1}{|c|}{ Parameters } & $\begin{array}{c}\text { PHB content } \\
(\mathrm{mgPHA} / \mathrm{gVS})\end{array}$ & $\begin{array}{c}\text { PHV } \\
(\mathrm{mgPHA} / \mathrm{gVSS})\end{array}$ & $\begin{array}{c}\text { PHA } \\
(\mathrm{mgPHA} / \mathrm{gVSS})\end{array}$ & $\begin{array}{c}\text { PHB:PHV } \\
(\mathrm{wt} \%)\end{array}$ \\
\hline Municipal Wastewater & $78.3 \pm 1.14$ & - & $78.3 \pm 1.14$ & $100: 0$ \\
\hline Husbandry Industry Wastewater & $55.2 \pm 0.65$ & $1.24 \pm 0.23$ & $56.5 \pm 2.68$ & $97.8: 2.2$ \\
\hline Fermentation Industry Wastewater & $42.2 \pm 1.62$ & - & $42.2 \pm 1.62$ & $100: 0$ \\
\hline
\end{tabular}




\section{Results and discussion}

\subsection{The optimum conditions for extracting PHAs from different sludge sources}

Figure 2a shows the effect of the sodium hypochlorite concentration of $\mathrm{NaOCl} / \mathrm{SDS}$ on PHA extraction from municipal wastewater sludge. The PHA purity increased when increasing the $\mathrm{NaOCl}$ concentration from $5 \%$ to $40 \%$ $(\mathrm{v} / \mathrm{v})$. However, the PHA purity did not significantly increase when the $\mathrm{NaOCl}$ concentration was more than $40 \%$ $(\mathrm{v} / \mathrm{v})$. Therefore, it is concluded that a $\mathrm{NaOCl}$ concentration of $40 \%$ is enough to destroy the cell walls and thereby release PHA monomers. Figure $2 b$ shows the effect of liquid-solid (L/S) ratio on the PHA purity and content. The $\mathrm{L} / \mathrm{S}$ ratio means the ratio of the volume of the $\mathrm{NaOCl}$ solution $(4.8 \%$ concentration) and the weight of dry sludge. It indicates that the magnitudes of the extracted PHA purity and content were increased with the increase of the $\mathrm{L} / \mathrm{S}$ ratio range from $0.33 \mathrm{~mL} / \mathrm{mg}$ to $1.0 \mathrm{~mL} / \mathrm{mg}$. Both PHA purity and content reached maximum levels $(100 \%$ and $58.0 \pm 7.19 \mathrm{mg}$ PHA/g VSS, respectively) when the L/S ratio was $1.0 \mathrm{~mL} / \mathrm{mg}$. PHB:PHV ratio changed from 100:0 (wt\%) to 75:25 (wt\%). However, both of the PHA purity and content sharply decreased when the $\mathrm{L} / \mathrm{S}$ ratio exceeded $1.0 \mathrm{~mL} / \mathrm{mg}$. This indicates that the sludge quantity was too high (due to the high L/S ratio) to destroy the sludge cells using the $\mathrm{NaOCl}$ solution, resulting in the decrease of PHA purity and content.

a)

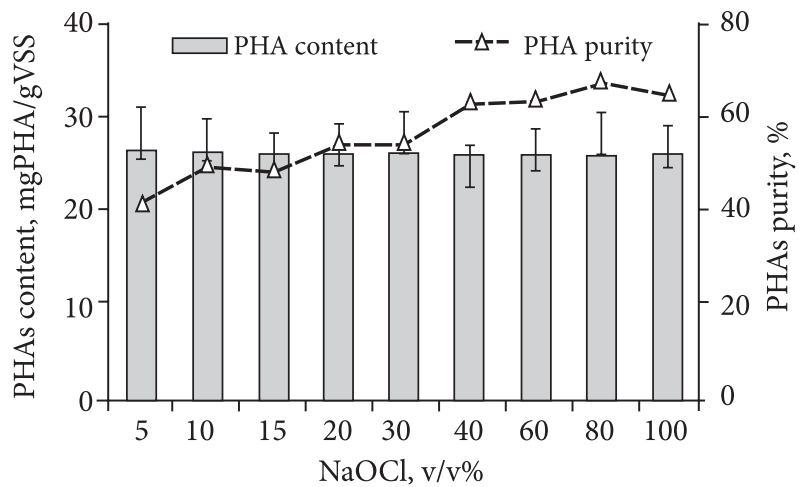

b)

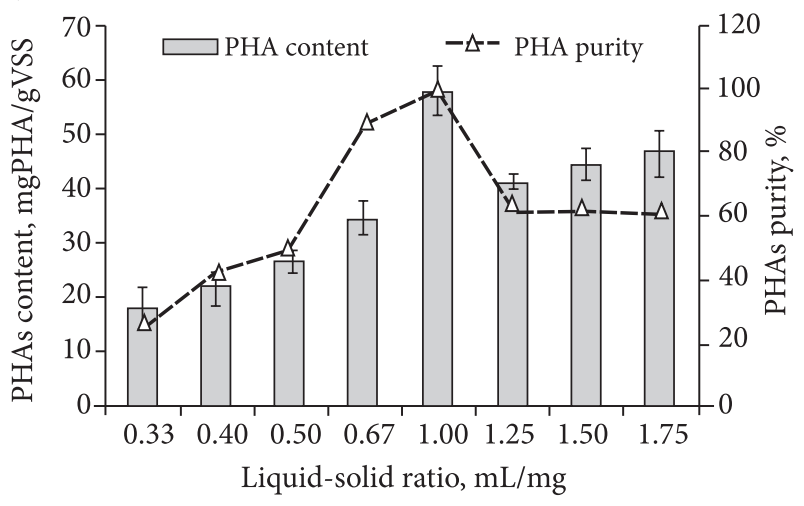

Figure 2. The optimum $\mathrm{NaOCl}$ concentration and $\mathrm{L} / \mathrm{S}$ conditions for extracting PHAs from municipal wastewater sludge
Figure 3a shows the results of PHA extraction from wastewater sludge from the husbandry industry. It is difficult to estimate the PHA purity extracted by $5 \%(\mathrm{v} / \mathrm{v})$ $\mathrm{NaOCl}$ because the $\mathrm{NaOCl}$ concentration was too low to effectively destroy the cell walls and extract PHAs. A statistics test indicates the $\mathrm{NaOCl}$ concentration has a significant effect on PHA purity $(\mathrm{p}<0.001)$. The highest PHA purity occurred with a $\mathrm{NaOCl}$ concentration of $15 \%(\mathrm{v} / \mathrm{v})$. Figure $3 \mathrm{~b}$ shows the effect of L/S ratio on PHA extraction. PHB:PHV ratio changed from 97.8:2.2 (wt\%) to 90.2:8.8 ( $w t \%)$. A statistics test indicates the $\mathrm{L} / \mathrm{S}$ ratio has a significant effect on PHA purity $(\mathrm{p}<0.001)$. The highest PHA purity occurred with an L/S ratio of $1.25 \mathrm{~mL} / \mathrm{mg}$.

Figure $4 \mathrm{a}$ shows the effect of the sodium hypochlorite concentration of $\mathrm{NaOCl} / \mathrm{SDS}$ on PHA extraction from wastewater sludge from the fermentation industry. The PHA purity increased when increasing $\mathrm{NaOCl}$ concentration from $5 \%$ to $20 \%(\mathrm{v} / \mathrm{v})$. However, the PHA purity decreased when the $\mathrm{NaOCl}$ concentration was larger than $20 \%(\mathrm{v} / \mathrm{v})$. A statistics test indicates $\mathrm{NaOCl}$ concentration has a significant effect on PHA purity $(\mathrm{p}<0.001)$. The highest PHA purity occurred at the $\mathrm{NaOCl}$ concentration of $20 \%(\mathrm{v} / \mathrm{v})$. Figure $4 \mathrm{~b}$ shows the effect of L/S ratio on PHA extraction. The PHA purity increased when increasing the $\mathrm{L} / \mathrm{S}$ ratio from 0.33 to $1.00 \mathrm{~mL} / \mathrm{mg}$, but the PHA content remained constant. PHB:PHV ratio changed from 100:0 (wt\%) to 64.7:35.3 (wt\%). However, the PHA purity decreased when the $\mathrm{L} / \mathrm{S}$ ratio was greater than $1.00 \mathrm{~mL} / \mathrm{mg}$.

a)

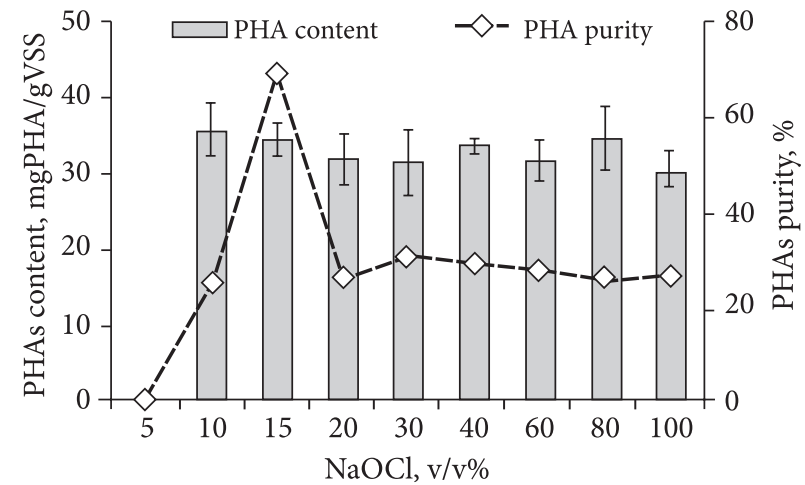

b)



Figure 3. The optimum $\mathrm{NaOCl}$ concentration and $\mathrm{L} / \mathrm{S}$ conditions for extracting PHAs from sludge from the husbandry industry 


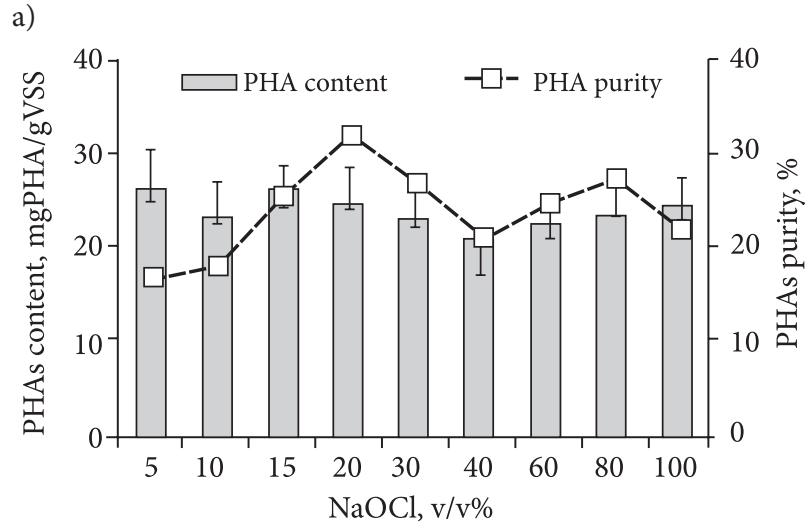

b)

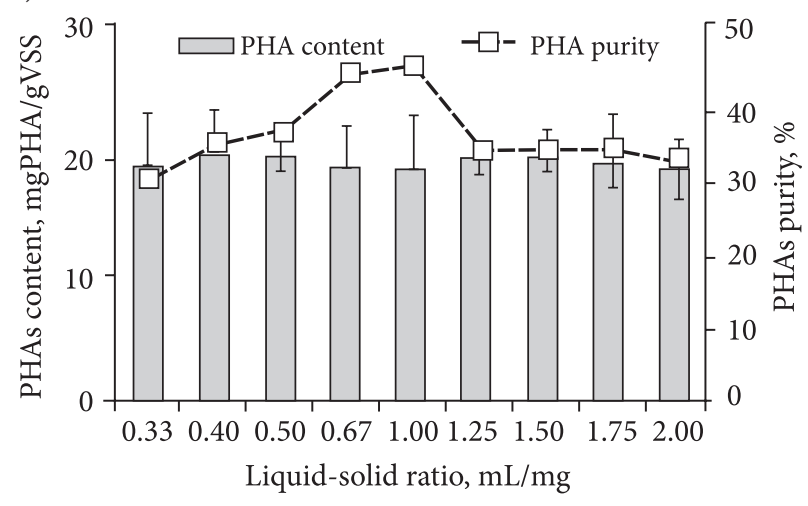

Figure 4. The optimum $\mathrm{NaOCl}$ concentration and $\mathrm{L} / \mathrm{S}$ conditions of for extracting PHAs from sludge from the fermentation industry

This might be ascribed to the fact that a higher L/S ratio resulted in an insufficient amount of sodium hypochlorite solution to efficiently rupture the microbial cell walls. A statistics test indicates the L/S ratio has a significant effect on PHA purity $(\mathrm{p}<0.001)$. The highest PHA purity occurred at an $\mathrm{L} / \mathrm{S}$ ratio of $1.00 \mathrm{~mL} / \mathrm{mg}$.

\subsection{Comparison of PHA purity and content extraction from different sludge sources}

As shown in Figure 5, the results indicated that waste sludge from the municipal wastewater treatment plant had the highest PHA purity (>99.5\%), followed by the sludge from the husbandry industry $(78.5 \pm 6.91 \mathrm{wt} \%)$ and the fermentation industry $(46.7 \pm 0.62 \mathrm{wt} \%)$. Figure 4 also shows that the PHA content obtained from the waste sludge from the municipal wastewater treatment plant was nearly equal to that from the husbandry industry, indicating both waste sludges are valuable for recovering PHAs.

Currently, more than 250 types of bacteria can synthesize PHAs, and relevant studies have indicated that a high PHA content can be obtained from pure bacterial cultures. For example, Don et al. (2006) used glucose as the carbon source to produce Hfx. mediterranei, in which a poly (hydroxyvalerate) content of $10.7 \%$ can be obtained. Kahar et al. (2004) used soybean oil to produce Cupriavidus necator and achieved a poly(hydroxybutyrate) content of $76 \%$. Kahar et al. (2005) produced Cupriavidus necator

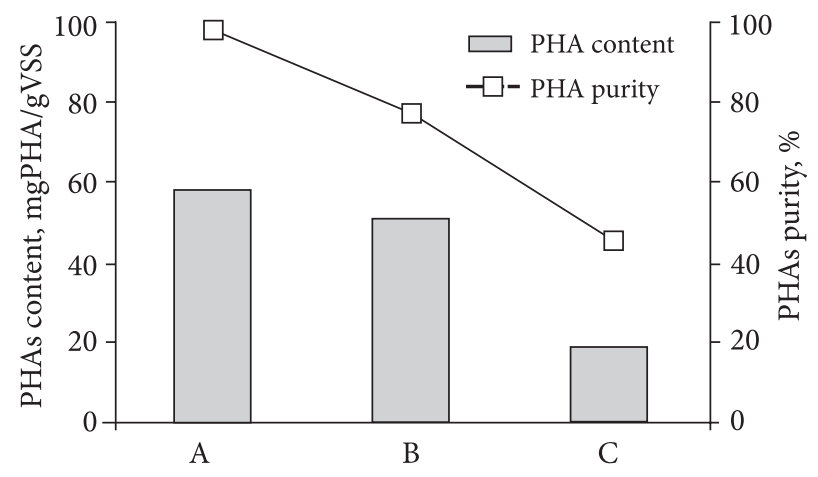

Figure 5. Comparison of PHA purity and content from different sludge sources (A: Municipal Wastewater, B: Husbandry Industry Wastewater, C: Fermentation Industry Wastewater)

by using glucose and obtained a poly(hydroxybutyrate) content of $80 \%$. In addition, some studies have also employed specific substrates (e.g., acetic acid) to cultivate activated sludge and thus obtain a high PHA content. For example, Punrattanasin (2001) used acetic acid to cultivate activated sludge with a PHA content of $47 \%$. Kasemsap and Wantawin (2007) also utilized acetic acid to cultivate activated sludge with a PHA content of $51 \%$. Although the PHA contents obtained in the aforementioned studies were higher than that obtained in this study, we directly used the actual waste sludge from wastewater treatment plants as the raw material, thus reusing the waste sludge to reduce environmental pollution problems and achieve the goal of resourcing and reducing waste sludge.

\subsection{Cost evaluation}

As the number of cost-consumption items that need to be discussed is too many, this study used waste sludge from urban wastewater processing as an example. The current phase of cost estimation only examines the commercial costs of raw materials. Experiments have proven that during the PHA extraction process, SDS and $\mathrm{NaOCl}$ can be reused; SDS could be reused up to 16 times, whereas $\mathrm{NaOCl}$ can be reused up to 14 times. Under the most appropriate domestic wastewater sewage condition, the obtained PHA content was $58.0 \pm 7.19 \mathrm{mg} \mathrm{PHA} / \mathrm{g}$ VSS, PHA purity was $99.5 \mathrm{wt} \%$, sludge MLVSS $=1800 \mathrm{mg} / \mathrm{L}=1.8 \mathrm{gVSS} / \mathrm{L}$, and the operating conditions were as follows: $\mathrm{NaOCl}$ conc. $=$ $40 \%(\mathrm{v} / \mathrm{v})$ and liquid-to-solid ratio $=1 \mathrm{~g} / \mathrm{L}$. The estimated chemical costs for extraction was USD 658/kg PHA.

\section{Conclusions}

This study developed a method to extract PHAs from waste sludges from municipal water treatment, the husbandry industry and the fermentation industry. Experimental results show that the PHA contents obtained from the waste sludge of the municipal wastewater treatment plant was nearly equal to that from the husbandry industry, indicating both waste sludge sources are valuable for recovery of PHAs. Taking the waste sludge of municipal 
wastewater treatment plants as an example, the chemical cost of the extraction method used in this study was about 685 US\$/kg PHAs, which is lower than the cost for producing PHAs through pure bacterial cultures (15-30 US\$/ kg PHAs).

\section{Acknowledgements}

This study was supported by a grant received from the National Science Council, Taiwan, Republic of China (NSC 99-2221-E-260 -005 -MY3).

\section{References}

Chen, G. Q. 2003. Production and applications of microbial polyhydroxyalkanoates, in Biodegradable polymers and plastics. Springer, 155-166.

Doi, Y.; Abe, C. 1990. Biosynthesis and characterization of a new bacterial copolyester of 3-hydroxyalkanoates and 3-hydroxy-. omega.-chloroalkanoates, Macromolecules 23(15): 3705-3707. https://doi.org/10.1021/ma00217a027

Don, T. M.; Chen, C. W.; Chan, T. H. 2006. Preparation and characterization of poly (hydroxyalkanoate) from the fermentation of Haloferax mediterranei, Journal of Biomaterials Science 17(12): 1425-1438. https://doi.org/10.1163/156856206778937208

García, I.; López, J.; Dorado, M.; Kopsahelis, N.; Alexandri, M.; Papanikolaou, S. 2013. Evaluation of by-products from the biodiesel industry as fermentation feedstock for poly (3-hydroxybutyrate-co-3-hydroxyvalerate) production by Cupriavidus necator, Bioresource Technology 130: 16-22. https://doi.org/10.1016/j.biortech.2012.11.088

Ghinea, C.; Gavrilescu, M. 2016. Costs analysis of municipal solid waste management scenarios: IASI - Romania case study, Journal of Environmental Engineering and Landscape Management 24(3): 185-199.

https://doi.org/10.3846/16486897.2016.1173041

Heinrich, D.; Andreessen, B.; Madkour, M. H.; Al-Ghamdi, M. A.; Shabbaj, I. I.; Steinbüchel, A. 2013. From waste to plastic: synthesis of poly (3-hydroxypropionate) in Shimwellia blattae, Applied and Environmental Microbiology 79: 3582-3589. https://doi.org/10.1128/AEM.00161-13

Jiang, X. J.; Ramsay, B. A.; Ramsay, J. A. 2014. Recovery of Medium-Chain-Length Poly (3-Hydroxyalkanoates) from Pseudomonas putida KT2440 by $\mathrm{NaOH}$ Digestion, Environmental Engineering Science 31: 49-54. https://doi.org/10.1089/ees.2013.0305

Kahar, P.; Agus, J.; Kikkawa, Y.; Taguchi, K.; Doi, Y.; Tsuge, T. 2005. Effective production and kinetic characterization of ultra-high-molecular-weight poly [(R)-3-hydroxybutyrate] in recombinant Escherichia coli, Polymer Degradation and Stability 87(1): 161-169.

https://doi.org/10.1016/j.polymdegradstab.2004.08.002

Kahar, P.; Tsuge, T.; Taguchi, K.; Doi, Y. 2004. High yield production of polyhydroxyalkanoates from soybean oil by Ralstonia eutropha and its recombinant strain, Polymer Degradation and Stability 83(1): 79-86.

https://doi.org/10.1016/S0141-3910(03)00227-1

Kasemsap, C.; Wantawin, C. 2007. Batch production of polyhydroxyalkanoate by low-polyphosphate-content activated sludge at varying $\mathrm{pH}$, Bioresource Technology 98(5): 10201027. https://doi.org/10.1016/j.biortech.2006.04.035

López-Abelairas, M.; García-Torreiro, M.; Lú-Chau, T.; Lema, J.; Steinbüchel, A. 2015. Comparison of several methods for the separation of poly (3-hydroxybutyrate) from Cupriavidus necator H16 cultures, Biochemical Engineering Journal 93: 250-259. https://doi.org/10.1016/j.bej.2014.10.018

Madkour, M. H.; Heinrich, D.; Alghamdi, M. A.; Shabbaj, I. I.; Steinbüchel, A. 2013. PHA recovery from biomass, Biomacromolecule 14: 2963-2972. https://doi.org/10.1021/bm4010244

Martino, L.; Cruz, M. V.; Scoma, A.; Freitas, F.; Bertin, L.; Scandola, M. 2014. Recovery of amorphous polyhydroxybutyrate granules from Cupriavidus necator cells grown on used cooking oil, International Journal of Biological Macromolecules 71: 117-123. https://doi.org/10.1016/j.ijbiomac.2014.04.016

Ojumu, T.; Yu, J.; Solomon, B. 2004. Production of polyhydroxyalkanoates, a bacterial biodegradable polymers, African Journal of Biotechnology 3(1): 18-24.

https://doi.org/10.5897/AJB2004.000-2004

Punrattanasin, W. 2001. The utilization of activated sludge polyhydroxyalkanoates for the production of biodegradable plastics: Dissertation. Virginia Polytechnic Institute and State University, USA.

Rai, R.; Keshavarz, T.; Roether, J.; Boccaccini, A. R.; Roy, I. 2011. Medium chain length polyhydroxyalkanoates, promising new biomedical materials for the future, Materials Science and Engineering: R: Reports 72: 29-47. https://doi.org/10.1016/j.mser.2010.11.002

Ramsay, J. A.; Berger, E.; Voyer, R.; Chavarie, C.; Ramsay, B. A. 1994. Extraction of poly-3-hydroxybutyrate using chlorinated solvents, Biotechnology Techniques 8: 589-594. https://doi.org/10.1007/BF00152152

Satoh, H.; Ramey, W.; Koch, F.; Oldham, W.; Mino, T.; Matsuo, T. 1996. Anaerobic substrate uptake by the enhanced biological phosphorus removal activated sludge treating real sewage, Water Science and Technology 34(1-2): 9-16.

Urtuvia, V.; Villegas, P.; Gonzalez, M.; Seeger, M. 2014. Bacterial production of the biodegradable plastics polyhydroxyalkanoates, International Journal of Biological Macromolecules 70: 208-213.

https://doi.org/10.1016/j.ijbiomac.2014.06.001 